\title{
Study of the Effect of Tamsulosin HCl (an Alpha-1 Receptor Antagonist) as a Medical Expelling Agent on Subsequent Ureteroscopic Procedure for Treatment of Lower Ureteric Stones
}

\author{
ALI M. GHONEIM, M.Sc.; AHMED M. AL-SAKKA, M.D.; MAGED M. RAGAB, M.D. and \\ ABD El-HAMID M. EL-BAHNASY, M.D.
}

The Department of Urology, Faculty of Medicine, Tanta University

\begin{abstract}
Background: Tamsulosin is an $\alpha-1 \mathrm{~A}$-specific blocker which induces selective relaxation of ureteral smooth muscle with subsequent inhibition of ureteral spasms and dilatation of the ureteral lumen and facilitates stone expulsion.

Aim of the Study: In this prospective randomized study we aimed to assess the efficacy of use of alpha blocker (tamsulosin $\mathrm{Hcl} 0.4 \mathrm{mg}$ ) on the outecome of ureteroscopic lithotripsy for distal ureteric stone.

Patients and Methods: In a prospective study by a randomized controlled clinical trial, which was performed from September 2016 to March 2017, about 50 patients underwent ureteroscopic lithotripsy with the pneumatic wolf lithotripsy. The patients were randomly divided into 2 groups: The study group including 25 patients, received tamsulosin with our traditional treatment (hydration and analgesic when required), and the control group with 25 patients who received placebo with traditional treatment. Patients prospectively will be evaluated for stone clearing rate by imaging at morning of URSL and at the end of 2 nd week including: (KUB and pelvi abdominal ultrasound)and they will be evaluated for number of colic episodes, analgesic consumption and post-operative complications (haematuria and UTI).

Results: The results showed that tamsulosin treatment group had short time of the procedure, easy extraction of the stone fragments, had low expulsion time, low urinary tract symptoms, least analgesic needs and low adverse effects.

Conclusions: Administration of $\alpha-1 \mathrm{~A}$-specific antagon istmade the procedure of short time, easy extraction of the stone fragments reduced analgesic dosage and colic episodes, rate of adverse effects after ureteroscopic lithotripsy of lower ureteral stones and decreased gravel expulsion time after URSL.
\end{abstract}

Key Words: Ureteroscopy - Lithotripsy $-\alpha-1 A$-specific blocker-Tamsulosin-Ureteral calculi.

Correspondence to: Dr. Ali M. Ghoneim, The Department of Urology, Faculty of Medicine, Tanta University

\section{Introduction}

BOTH $\alpha_{1 \mathrm{~A}}$ and $\alpha_{1 \mathrm{D}}$ adrenergic receptors are present more densely in the distal $1 / 3$ of ureter (including intramural part) than other adrenergic receptors. When stimulated, they inhibit the basal tone, peristaltic wave frequency and the ureteral contractions even in the intramural part of lower ureter. Alpha one antagonists have a crucial impact in spontaneous painless elimination of the stones smaller than $8 \mathrm{~mm}$ located in the distal part of the ureter [1].

They may work on the obstructed ureter by inducing an increase in the intraureteral pressure gradient around the stone by increasing the urine bolus above the stone (and consequently an increase in intraureteral pressure above the stone) as well as decreased peristalsis below the stone (and consequently a decrease in intraureteral pressure below the stone) in association with the decrease in micturition pressure even at the bladder neck, thereby an increased chance of stone expulsion [2]

To facilitate ureteral stone expulsion and decrease post-operative complications, recent studies have recommended a Medical Expelling Therapy (MET) with calcium antagonists, corticosteroids and $\alpha-1$ blockers $[3,4]$.

The efficacy of minimally invasive therapies such as Extracorporeal Shock Wave Lithotripsy (ESWL) and ureteroscopy for distal ureter stones has been proven by recent studies [5]. However, these minimally invasive therapy modalities have some drawbacks; they are not risk free, sometimes they could even be problematic and also they are quite expensive [6]. Moreover the success rate of these techniques is affected by several factors such 
as stone size and location, machinery type and operator's experience; in addition, secondary procedures and occasional re-treatments are necessitated [7].

Based on these findings, we hypothesized that use of $\alpha^{-}{ }_{1 \text { A }}$ blocker as apart of expulsive therapy for ureteric stones may facilitate any subsequent ureteroscopic manipulation for treatment of the stones that failed medical treatment.

\section{Objectives:}

In this prospective randomized study we aimed to assess the efficacy of use of alpha blocker (tamsulosin $\mathrm{Hcl} 0.4 \mathrm{mg}$ ) on the outcome of ureteroscopic lithotripsy for distal ureteric stone.

\section{Patients and Methods}

This study was performed on 50 patients with distal ureteric stone presented to Tanta University Hospital, Urology Department in whome uretroscopic lithotripsy was chosen for treatment of the distal ureteric stones from September 2016 to March 2017. The study was approved by the Ethics Committee of Tanta University.

According to the inclusion criteria, all patients had radiolucent or radio opaque distal ureteric stone with Stone size up to $1 \mathrm{~cm}(\leq 1 \mathrm{~cm})$, where as patients with active urinary tract infections, major medical conditions (i.e un controlled diabetes), history of hypersensitivity to ct-blockers, ureteral stricture, previous ureteric surgery, spontaneous passage of the stones, childeren or pregnant women were excluded.

Stone presence and its characteristics were diagnosed by Kidney-Ureter-Bladder X-ray (KUB), pelvi-abdominal ultrasonography Computed Tomography (C.T) and Intravenous Urography (IVU) when indicated.

All patients were randomely divided into 2 group using a coin toss. In GroupA, alpha blocker (tamsulosin $\mathrm{Hcl} 0.4 \mathrm{mg}$ ) was taken at least 2 weeks before the procedure and Group B, no alpha blocker was taken before the procedure. All patients received traditional treatment (hydration and analgesic when required).

The total number of patients for this study was 50 patients underwent ureteroscopic lithotripsy with the pneumatic wolf lithotripsy. (25 patients for each group).

All patients that met the inclusion criteria were subjected to URSL after providing an informed written consent. The operation was performed with spinal or general anesthesia. All patients underwent ureteroscopic lithotripsy with a $8.5 \mathrm{Fr}$ semi-rigid ureteroscope and a 1.9 Fr pneumatic probe until fragments were smaller than about $2 \mathrm{~mm}$ in diameter which allowed for spontaneous passage.

During URS procedure, all patients were evaluated for, time of the procedure starting from localization of ureteric orifice till stenting of the ureter (if needed), need for dilatation of ureteric orifice, size of fragment extracted by ureteric stone forceps and how many trials for each fragment and need to post-procedure stenting based on the status of the ureteral wall at the end of the procedure.

\section{Patients follow-up:}

After the procedure, all patients were asked to filter their urine to detect any possible fragments or stone expulsions and the first assessment of stone clearing rate was performed by imaging during the morning after URSL and then the patients were evaluated at the end of the first and second week after the procedure, with a clinical visit that included KUB and pelvi abdominal ultrasonography. The number of colic episodes, lower urinary tract symptoms, amounts of analgesic consumption and adverse effects of medical therapy were evaluated.

The URS complications were reported according to the modified Clavien grading system. Grade I (events without adverse consequences for the patient), grade II (complications comprising blood transfusions or urinary tract infection), grade IIIa (complications requiring intervention under local anaesthesia), grade IIIb (complications requiring intervention under general anaesthesia), grade IVb (single organ dysfunction, such as myocardial infarction and renal failure), grade IVb (urosepsis or multi organ dysfunction) and grade $\mathrm{V}$ (death) [8].

\section{Statistical analysis:}

Data were collected, presented and statically analyzed using graph pad computer program. Statistical presentation and analysis of the present study was conducted, using the mean, standard deviation, and chi-square test by SPSS V.20. Significance was considered as a $p$-value $<0.05$.

\section{The used tests were:}

1- Chi-square test: For categorical variables, to compare between different groups.

2- Fisher's exact or monte carlo correction:Correction for chi-square when more than $20 \%$ of the cells have expected count less than 5 . 
3- Student t-test: For normally quantitative variables, to compare between two studied groups.

\section{Results}

A total of 50 patients met the inclusion criteria; were included and underwent URSL using semirigid Wolf ureteroscope ( $8.5 \mathrm{fr}$ ) with pneumatic lithotripter (Swiss Lithoclast) with 25 patients in each group.

\section{The results of the study included:}

1- Pre-operative data: There were no statistically significant differences between patients in the two groups in regard to their demographic and stone characteristics (Tables 1,2).

Table (1): Comparison between the two studied groups according to demographic data.

\begin{tabular}{|c|c|c|c|c|c|c|}
\hline & \multicolumn{2}{|c|}{$\begin{array}{l}\text { Tamsulosin } \\
(\mathrm{n}=25)\end{array}$} & \multicolumn{2}{|c|}{$\begin{array}{l}\text { Non tamsulosin } \\
\quad(n=25)\end{array}$} & \multirow{2}{*}{$\begin{array}{l}\text { Test } \\
\text { of } \\
\text { sig. }\end{array}$} & \multirow{2}{*}{$p$} \\
\hline & No. & $\%$ & No. & $\%$ & & \\
\hline \multicolumn{7}{|l|}{ - Gender: } \\
\hline Male & 15 & 60.0 & 15 & 60.0 & $\chi^{2}=$ & 0.774 \\
\hline Female & 10 & 40.0 & 10 & 40.0 & 0.082 & \\
\hline \multicolumn{7}{|l|}{ - Age (years): } \\
\hline Min.-max. & \multirow{2}{*}{\multicolumn{2}{|c|}{$\begin{array}{l}21.0-70.0 \\
41.68 \pm 10.36\end{array}$}} & \multicolumn{2}{|c|}{$21.0-64.0$} & \multirow[t]{3}{*}{$t=0.654$} & \multirow[t]{3}{*}{0.516} \\
\hline Mean \pm SD & & & & 11.66 & & \\
\hline Median & 43.0 & & 36. & & & \\
\hline \multicolumn{7}{|c|}{ - Episodes of stone: } \\
\hline No & 15 & 60.0 & 17 & 68.0 & $\chi=$ & \multirow[t]{2}{*}{0.556} \\
\hline Yes & 10 & 40.0 & 8 & 32.0 & 0.347 & \\
\hline \multicolumn{7}{|c|}{$\begin{array}{l}\text { - Previous passage of } \\
\text { stone: }\end{array}$} \\
\hline No & 18 & 72.0 & 20 & 80.0 & $\chi=$ & \multirow[t]{2}{*}{0.508} \\
\hline Yes & 7 & 28.0 & 5 & 20.0 & 0.439 & \\
\hline \multicolumn{7}{|l|}{ - Previous URS: } \\
\hline No & 22 & 88.0 & 22 & 88.0 & $\chi=$ & $\mathrm{FEp}=$ \\
\hline Yes & 3 & 12.0 & 3 & 12.0 & 0.000 & 1.000 \\
\hline \multicolumn{7}{|c|}{ - Time since diagnosis: } \\
\hline $2 \mathrm{w}$ & 10 & 40.0 & 7 & 28.0 & 0.806 & 0.668 \\
\hline $3 \mathrm{w}$ & 9 & 36.0 & 11 & 44.0 & & \\
\hline $4 \mathrm{w}$ & 6 & 24.0 & 7 & 28.0 & & \\
\hline
\end{tabular}

Table (2): Comparison between the two studied groups according to stone criteria (side, size and radioopacity).

\begin{tabular}{|c|c|c|c|c|c|c|}
\hline & \multicolumn{2}{|c|}{$\begin{array}{l}\text { Tamsulosin } \\
\qquad(n=25)\end{array}$} & \multicolumn{2}{|c|}{$\begin{array}{l}\text { Non tamsulosin } \\
\qquad(\mathrm{n}=25)\end{array}$} & \multirow{2}{*}{$\begin{array}{c}\text { Test } \\
\text { of } \\
\text { sig. }\end{array}$} & \multirow{2}{*}{$p$} \\
\hline & No. & $\%$ & No. & $\%$ & & \\
\hline \multicolumn{7}{|l|}{ Side: } \\
\hline Right & 17 & 68.0 & 12 & 48.0 & $\chi^{2}=$ & $\mathrm{MCp}=$ \\
\hline Left & 8 & 32.0 & 13 & 52.0 & 3.362 & 0.160 \\
\hline \multicolumn{7}{|l|}{ Size (cm): } \\
\hline Min.-max. & \multicolumn{2}{|c|}{$0.60-1.0$} & \multicolumn{2}{|c|}{$0.60-1.0$} & $t=$ & \multirow[t]{3}{*}{0.165} \\
\hline Mean \pm SD & \multirow{2}{*}{\multicolumn{2}{|c|}{$\begin{array}{l}0.88 \pm 0.14 \\
0.90\end{array}$}} & \multicolumn{2}{|c|}{$0.82 \pm 0.14$} & 1.411 & \\
\hline Median & & & & & & \\
\hline \multicolumn{7}{|c|}{ Stone radio-opacity: } \\
\hline Radio-opaque & 15 & 60.0 & 17 & 68.0 & 0.347 & 0.556 \\
\hline Radiolucent & 10 & 40.0 & 8 & 32.0 & & \\
\hline
\end{tabular}

\section{2- Intra-operative data:}

A- Access the ureter and need for dilatation of UO: There was statistically significant difference between both groups as regard the dilatation of UO $(p$-value $=0.031)($ Table 3$)$.

Table (3): Comparison between the two studied groups according to dilatation of UO.

\begin{tabular}{|c|c|c|c|c|c|c|}
\hline & \multicolumn{2}{|c|}{$\begin{array}{l}\text { Tamsulosin } \\
\quad(n=25)\end{array}$} & \multicolumn{2}{|c|}{$\begin{array}{l}\text { Non tamsulosin } \\
\qquad(\mathrm{n}=25)\end{array}$} & \multirow{2}{*}{$\chi^{2}$} & \multirow{2}{*}{$p$} \\
\hline & No. & $\%$ & No. & $\%$ & & \\
\hline \multicolumn{7}{|c|}{ Dilatation of UO: } \\
\hline No & 21 & 84.0 & 14 & 56.0 & 4.666 & $0.031 *$ \\
\hline Yes & 4 & 16.0 & 11 & 44.0 & & \\
\hline
\end{tabular}

B- Need for a stent: There was statistically significant difference between both groups as regard the use of a stent $(p$-value $=0.022)($ Table 4).

Table (4): Comparison between the two studied groups according to stent or not.

\begin{tabular}{|c|c|c|c|c|c|c|}
\hline & \multicolumn{2}{|c|}{$\begin{array}{l}\text { Tamsulosin } \\
\qquad(n=25)\end{array}$} & \multicolumn{2}{|c|}{$\begin{array}{l}\text { Non tamsulosin } \\
\qquad(n=25)\end{array}$} & \multirow{2}{*}{$x^{2}$} & \multirow{2}{*}{$p$} \\
\hline & No. & $\%$ & No. & $\%$ & & \\
\hline \multicolumn{7}{|l|}{ Stent or not: } \\
\hline NO & 16 & 64.0 & 7 & 28.0 & $6.521 *$ & $0.022 *$ \\
\hline Open tip & 6 & 24.0 & 7 & 28.0 & & \\
\hline JJ & 3 & 12.0 & 11 & 44.0 & & \\
\hline
\end{tabular}

C- Operative time: There was statistically significant difference between both groups as regard the operative time $(p$-value $=<0.001)($ Table 5).

Table (5): Comparison between the two studied groups according to time of procedure.

\begin{tabular}{llllll}
\hline & \multicolumn{2}{c}{ Tamsulosin Non tamsulosin } \\
$(\mathrm{n}=25)$ & \multicolumn{1}{c}{$\begin{array}{c}(\mathrm{n}=25) \\
\end{array}$} & & & $p$ \\
\hline $\begin{array}{l}\text { Time of procedure } \\
\text { (minutes): }\end{array}$ & & & & \\
$\quad$ Min.-max. & $20.0-45.0$ & $30.0-50.0$ & $5.005^{*}$ & $<0.001^{*}$ \\
Mean \pm SD. & $30.60 \pm 6.97$ & $40.0 \pm 6.29$ & & \\
Median & 30.0 & 40.0 & & \\
\hline
\end{tabular}

3- Complications rate: There were statistically significant difference between both groups as regard post-operative complications (colic episodes, analgesic consumption, fever and haematuria) ( $p$-value $=<0.001,<0.022,0.047 \& 0.047$ respectively) (Table 6).

As regard the hospital stay in our study, it was ranged from 2.0-4.0 days with a mean of 3.01 \pm 0.97 $\& 3.03 \pm 0.88$ days for both groups (A \& B) respectively (Table 7). 
Table (6): Comparison between the two studied groups according to complication rate.

\begin{tabular}{|c|c|c|c|c|c|c|}
\hline \multirow{2}{*}{ Complication rate } & \multicolumn{4}{|c|}{ 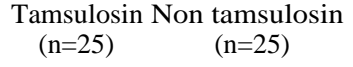 } & \multirow{2}{*}{$\begin{array}{c}\text { Test } \\
\text { of } \\
\text { sig. }\end{array}$} & \multirow{2}{*}{$p$} \\
\hline & No. & $\%$ & No. & $\%$ & & \\
\hline \multicolumn{7}{|l|}{ Analgesics (opioid): } \\
\hline No & 18 & 72.0 & 10 & 40.0 & $\chi=$ & $<0.022 *$ \\
\hline Yes & 7 & 28.0 & 15 & 60.0 & $5.195^{*}$ & \\
\hline \multicolumn{7}{|l|}{ Colic episodes: } \\
\hline Min.-max. & \multicolumn{2}{|c|}{$0.0-2.0$} & \multicolumn{2}{|c|}{$0.0-5.0$} & $\mathrm{U}=$ & \multirow[t]{3}{*}{$<0.001^{*}$} \\
\hline Mean \pm SD. & \multicolumn{2}{|c|}{$0.72 \pm 0.74$} & \multicolumn{2}{|c|}{$2.32 \pm 1.38$} & $104.50^{*}$ & \\
\hline Median & \multicolumn{2}{|l|}{1.0} & \multicolumn{2}{|c|}{3.0} & & \\
\hline \multicolumn{7}{|l|}{ Fever: } \\
\hline No & 22 & 88.0 & 16 & 64.0 & $\chi^{2}=$ & \multirow[t]{2}{*}{$0.047^{*}$} \\
\hline Yes & 3 & 12.0 & 9 & 36.0 & 3.947 & \\
\hline \multicolumn{7}{|l|}{ Haematuria: } \\
\hline No & 22 & 88.0 & 16 & 68.0 & $\chi=$ & \\
\hline Yes & 3 & 12.0 & 9 & 32.0 & 3.94 & $0.047 *$ \\
\hline
\end{tabular}

There was no statistically significant difference between both groups as regard the hospital stay $(p$-value $=0.390)($ Table 7$)$.

Table (7): Comparison between the two studied groups according to hospital stay.

\begin{tabular}{|c|c|c|c|c|}
\hline & $\begin{array}{l}\text { Tamsulosin } \\
\quad(n=24)\end{array}$ & $\begin{array}{l}\text { Non tamsulosin } \\
\qquad(n=22)\end{array}$ & $\mathrm{U}$ & $p$ \\
\hline \multicolumn{5}{|l|}{ Hospital stay: } \\
\hline Min.-max. & $2.0-4.0$ & $2.0-4.0$ & 0.868 & 0.390 \\
\hline Mean $\pm S D$ & $3.01 \pm 0.97$ & $3.03 \pm 0.88$ & & \\
\hline Median & 3.0 & 3.0 & & \\
\hline
\end{tabular}

\section{4- The overall success rate (stone free rate and} retreatment rate):

A- Failure of the procedure: Reported only in one patient (4\%) in group B which was due to trauma to the ureter and bleeding during fragmentation of the stone which treated with stent placement for 2 weeks and 2 nd URSL (Table 8).

$B$ - Migration of the stone or part of stone: Reported only in 1 patient (4\%) in group A and 2 patient (8\%) in group B and they were treated with ESWL (Table 8).

As regard stone free rate in group A, it was $(96 \%)$ and in group B was (88\%) and there was no significant difference between both groups ( $p$ value $=0.740)($ Table 8$)$.

In the current study, regarding the modified Clavien classification system, mild and moderate complications (Grades I, II and III) were reported in both groups, consisting of mucosal injuries, haematuria, fever and colic episodes required opioids which significantly decreased in the group prepared with tamsulosin (Table 9).
Failed procedure was reported only in one patient (4\%) in group B which was due to trauma to the ureter and bleeding during fragmentation of the stone which treated with stent placement for 2 weeks and 2 nd URSL (Table 9).

Stone migration was seen in one patient (4\%) in group A and two patients (8\%) in group B and they were treated with ESWL (Table 9).

Table (8): Comparison between the two studied groups according to stone free rate and retreatment rate.

\begin{tabular}{lllllll}
\hline & $\begin{array}{c}\text { Tamsulosin } \\
(\mathrm{n}=25)\end{array}$ & $\begin{array}{c}\text { Non tamsulosin } \\
(\mathrm{n}=25)\end{array}$ & \multirow{2}{c}{$\chi^{2}$} & $\mathrm{MC}_{p}$ \\
\cline { 2 - 5 } & No. & $\%$ & No. & $\%$ & & \\
\hline $\begin{array}{l}\text { Stone free rate: } \\
\quad\end{array}$ & 0 & 0.0 & 1 & 4.0 & 1.955 & 0.740 \\
$\quad$ Failed & 24 & 96.0 & 22 & 88.0 & & \\
$\quad$ Yes & 1 & 4.0 & 2 & 8.0 & & \\
$\quad$ Migrated & & & & & & \\
Retreatment rate: & & & & & & \\
$\quad$ No & 24 & 96.0 & 22 & 88.0 & 2.197 & 0.743 \\
$\quad$ ESWL & 1 & 4.0 & 2 & 8.0 & & \\
$\quad$ URS & 0 & 0.0 & 1 & 4.0 & & \\
\hline
\end{tabular}

Table (9): The complications and their grades according to the MCCS.

\begin{tabular}{|c|c|c|c|c|c|}
\hline Grade & Complications & $\begin{array}{l}\text { Tamsulosin } \\
\text { group } \\
(\mathrm{n}=25)\end{array}$ & $\begin{array}{l}\text { Non } \\
\text { tamsulosin } \\
\text { group } \\
(\mathrm{n}=25)\end{array}$ & $\begin{array}{c}\text { Overall } \\
(n=50)\end{array}$ & $\begin{array}{c}p- \\
\text { value }\end{array}$ \\
\hline \multicolumn{6}{|l|}{ Minor: } \\
\hline \multirow[t]{3}{*}{ Grade I } & - Fever & 3 & 9 & 12 & 0.047 \\
\hline & - Mucosal injury & 1 & 1 & 2 & 0.505 \\
\hline & - Hematuria & 3 & 9 & 12 & 0.047 \\
\hline Grade II & $\begin{array}{l}\text { - Colic needed } \\
\text { opioids }\end{array}$ & 7 & 15 & 22 & 0.020 \\
\hline \multicolumn{6}{|l|}{ Major: } \\
\hline Grade IIIa & $\begin{array}{l}\text { Proximal stone } \\
\text { migration }\end{array}$ & 1 & 2 & 3 & 0.551 \\
\hline $\begin{array}{l}\text { Grade } \\
\text { IIIb }\end{array}$ & $\begin{array}{l}\text { - Failed } \\
\text { procedure } \\
\text { needed 2nd } \\
\text { URSL }\end{array}$ & 0 & 1 & 1 & 0.024 \\
\hline
\end{tabular}

MCCS: Modified Clavien Classification System.

\section{Discussion}

The urolithiasis is a common and increasing condition with the global prevalence of urinary tract stones has been estimated to be between $2 \%$ to $20 \%$ and affecting $15 \%$ of men and $5 \%$ of women with a total ratio about 3:1 between males $\&$ females [9]. The life time recurrence rate is approximately $50 \%$, and about $33-54 \%$ of whole urinary stones are ureteral stones, where $70 \%$ of these ureteral stones are located in the distal part of the ureters [9]. 
The incidence of stones in the current study was varying regarding the gender with a percentage of $60 \%$ in men \& $40 \%$ in women with a total ratio about $3: 2$ between males $\&$ females and there was a slightly increased incidence of stones in females that may be due to changes in the life style \& environment or may be due to the small sample of our study.

The most common component of urinary calculi is calcium, which is a major constituent in nearly $75 \%$ of stones. Calcium oxalate makes up about $60 \%$ of all stones; mixed calcium oxalate and hydroxyapatite, $20 \%$; and brushite stones, $2 \%$. Both uric acid and struvite (magnesium ammonium phosphate) stones occur approximately $10 \%$ of the time, whereas cystine stones are rare $(1 \%)$. Stones associated with medications and their by-products such as triamterene, adenosine, silica, indinavir and ephedrine are very uncommon and usually preventable [10].

Opacity implies the presence of substantial amounts of calcium within the stone. Calcium phosphate stones are the most radiodense stones, being almost as dense as bone. Calcium oxalate stones are slightly less radiodense [11].

In the current study regarding the stone radioopacity detected in the pre-operative plain film; the incidence of radio-opaque stones was about $64 \%$ and radiolucent stones about $36 \%$.

Due to recent advances in the field of endourology and miniaturisation of the new instruments, there was a large shift in the active treatment of ureteral stones away from open surgery to minimally invasive methods (e.g. ESWL and URS).

The choice of the ideal type of therapy is largely related to the type of equipment available, the type, size, site, degree of impaction of the stone, patient preference and experiences of the surgeon [12,13]

Current guidelines recommend ureteroscopy over other treatment modalities for the majority of ureteric stones [14]

Ureteoscopy (URS) is one of the most common procedures performed for upper and lower ureteral disorders. However, URS is associated with potential risks and complications [15]

Ureteroscopic complications are well known, but the predictive factors remain unclear. Careful attention to the selection of instruments and techniques is important to reducing complications related to URS procedures [15].
Substantial advances in URS have resulted in the procedure being incorporated into routine urological practice in many centres worldwide. An abundance of clinical data and technological progression has enabled the development of new solutions, which have increased the efficacy of URS and reduced associated morbidity and costs [16] .

Although ureteral stones less than $5 \mathrm{~mm}$ could pass in up to $98 \%$ of cases, fragmented stones following lithotripsy interventions cause some degree of ureteral wall congestion and oedema, interfering with straight gravel passage and even leading to stone impaction.

Thus, the use of MET may facilitate stone passage and decrease the time for spontaneous stone passage as well as reducing possible risks of renal damage due to prolonged partial ureteral obstruction (greater than 4-6 weeks) and persistent pain or UTI $[17,18]$

Many studies have demonstrated excellent results of MET use for treatment of distal ureteric stones. In terms of stone expulsion and control of ureteric colic, drugs (e.g. calcium channel blockers, corticosteroids, a 1 ARblockers) that can modulate the function of the ureter, which may be obstructed by a stone, can be used. Alpha-1 blockers, in particular $\alpha_{1 \mathrm{~A}}$ blockers (e.g. tamsulosin), are preferred due to the prevalence of a specific adrenoceptor subtype in the distal part of the ureter. Tamsulosin acts by relaxation the ureteral wall muscle, facilitating gravels expulsion after the procedure and aiding the advancement of instruments through the ureter for improved access of the ureter and stones [12].

URSL has high efficacy and success rates for distal ureteric stones, but it is more expensive and more invasive [13]. So, if adjunct therapy such as MET is used before or when the ureteroscope is advanced prior to accessing the stone, these complications can be reduced.

The research group prospectively analysed different factors that might affect the success and complications of management of ureteric stones with URS. We found that endoscopic interventions without preparation with tamsulosin were associated with increased complications.

Although routine ureteral dilatation was necessary for ureteroscopy using the early model larger (>10 Fr) ureteroscopes, this has been brought into question with the advent of smaller caliber rigid and flexible ureteroscopes. Prior to the advent of 
balloon dilators, ureteral dilatation was performed with serial dilators. The shearing forces applied by these dilators often resulted in linear tears of the mucosa, significant tissue trauma and VUR (vesico ureteral reflux).

Garvin and Clayman demonstrated a $20 \%$ incidence of VUR after ureteral dilation to $24 \mathrm{Fr}$ [19]. In 1999, Richter et al., found a $10 \%$ incidence of VUR after ureteral dilation to $13.5 \mathrm{Fr}$ [20]. These authors followed their patients prospectively; the patients demonstrated complete resolution of reflux at 2 weeks postoperatively.

Stoller et al., found that ureteral dilatation was necessary in $16 \%$ of their population using semirigid ureteroscopes ranging from 9.5 to $12.5 \mathrm{Fr}$ and concluded that routine dilatation of the ureteral orifice was not necessary [21]. Kourambas et al., noted that $24 \%$ of their patients required dilation using 6.5-Fr semirigid and 7.5-Fr flexible ureteroscopes [22].

Indeed, although ureteral dilatation was considered an essential step in ureteroscopy, the authors found that routine dilatation is infrequently necessary in current clinical practice and therefore, routinely access the ureter atraumatically without ureteral dilatation in most cases.

In the current study, it was noted that ureteroscoy for patients received tamsulosin was more accessible as the ureteral orifice was easier to locate, distinsable, and easily intubated with no need for dilatation before the beginning of the procedure. Thus, the intramural ureter can be approached without ureteral dilatation which eliminates the potential trauma and mucosal irritation.

In patients received tamsulosin, the ureteric orifices were easily identified and dilatable infront of the fluid jet from the URS and the ureteroscope could be inserted easily without dilatation, primarily due to the muscle-relaxing effect of tamsulosin. In the current study, it was showed that the need of ureteric orifice dilatation varied significantly between the two groups as the ureteric orifice needed to be dilated in 4 patients $(16 \%)$ in the tamsulosin group and in 11 patients $(44 \%)$ in the non tamsulosin group. In twenty one (21) patients in tamsulosin group, the initial introduction of the URS was easy enough to continue the whole procedure without need to dilatation.

On the other hand, in four [4] patients in the tamsulosin group, the advancement of the URS was not that easy to continue the procedure depending on the hydrodistension alone. In this group of patients [4] as well in another [11] patients in the non tamsulosin group; balloon dilatation of the UO was done using $7 \mathrm{~cm} / 15 \mathrm{Fr}$ uromax ureteral dilatation ballon then the URS was performed uneventful.

Regarding the size of extracted stone fragments in our study, there was no significant difference between both groups with the mean size of $4.46 \mathrm{~mm}$ $\& 4.23 \mathrm{~mm}$ respectively in group A and B. However, when we looked at the data of the groups of patients who underwent URSL without initial dilatation (21 patients in tamsulosin group \& 14 patients in non tamsulosin group); we noticed that repeated insertion of the URS as well as extraction of the stone fragments was easier among the patients in tamsulosin group.

The current standard of care regarding stenting after ureteroscopy is evolving. Clearly, a large number of patients undergoing uncomplicated diagnostic and/or therapeutic ureteroscopy may safely remain unstented. Nevertheless, common sense and clinical judgment should prevail. Patients undergoing complicated ureteroscopy with mucosal trauma, perforation, impacted stones, solitary kidneys and bilateral ureteroscopy should be stented [23-25]

In 2002, a randomized controlled trial evaluated 60 patients, 30 stented, and 30 non-stented, after uncomplicated ureteroscopic lithotripsy with an electrohydraulic lithotripter. Patients without ureteral stents were found to have similar stone-free rates, renal function recovery, pain reduction, and less irritative voiding symptoms as compared to those patients in which stents were placed. The authors found it was not necessary to place a ureteral stent routinely after uncomplicated ureteroscopic lithotripsyn for stones smaller than $1 \mathrm{~cm}$ [23].

In 2007, Nabi et al., published a meta-analysis of nine randomized controlled trials examining the outcomes with and without stenting after ureteroscopy. The authors found a significantly higher incidence of dysuria and frequency or urgency in stented patients. They concluded that stenting in uncomplicated ureteroscopy leads to considerable morbidity [24]

In 2008, a systematic review of the same nine randomized controlled trials, reported similar findings to the previous meta-analysis study with respect to stent morbidity and lack of long-term advantages. However, the systematic review concluded stenting in an uncomplicated patient is not mandatory [25] 
In our study, it was noted that the need for stent varied significantly between the two groups as, only 9 patients $(36 \%)$ needed a stent ( 6 open tip urteric catheter for $48 \mathrm{~h} \mathrm{[24 \% ]}$ and 3 double J stent [12\%]) in tamsulosin group and 18 patients (72\%) in the other group (7 open tip urteric catheter for 48h [28\%] and 11 double J stent [44\%]) and all patients underwent double $\mathrm{J}$ stent insertion after the procedure in both groups developed some LUTS especially in group B and treated as usual.

One of the important findings of this research was the short operative time which was observed among patients who received tamsulosin preoperatively.

Regarding complications of ureteroscopy, the incidence of major and minor complications has decreased significantly with increased success rate since the inception of ureteroscopy especially with the advent of improved imaging, smaller diameter endoscopes, and increasing surgeon experience.

Carter et al., reported a $67 \%$ success rate for ureteroscopic stone removal with a $15 \%$ open ureterolithotomy rate secondary to ureteroscopic failure [26].

The main complication was failure to access the ureter or reach the stone in $15 \%$ of patients. Major ureteric injury requiring open repair occurred in $2.4 \%$ of patients with additional perforations managed conservatively in $3.2 \%$.

Flam et al., subsequently reported an overall success rate of $78 \%$ for ureteroscopic stone removal with ureteral injury occurring in $4 \%$ of patients [27].

These studies uniformly employed rigid endoscopes larger than $10 \mathrm{Fr}$. Ureteral dilatation to 18 Fr, using a balloon or serial dilators, was standard practice.

Harmon et al., reported on the impact of technological advancement and surgeon experience on ureteroscopic outcomes with the overall complication rate decreased from 20 to $12 \%$ and the rate of significant ureteral injury decreased from 5.2 to $1.5 \%$ and overall ureteroscopic success rate increased from 86 to $96 \%$ [28].

In the current study, regarding the modified Clavien classification system, mild and moderate complications (grades I, II and III) were reported in both groups, consisting of mucosal injuries, haematuria, fever and colic episodes required opioids which significantly decreased in the group prepared with tamsulosin. All these complications were managed conservatively.

Failed procedure was reported only in one patient (4\%) in group B which was due to trauma to the ureter and bleeding during fragmentation of the stone which treated with stent placement for 2 weeks and 2 nd URSL.

Stone migration was seen in one patient $(4 \%)$ in group A and two patients (8\%) in group B. Due to equipment failure (shortage of equipment for follow-up of the migrating stones, such as flexible ureteroscopy and laser lithotripsy for fragmenting or extracting the migrating stones), migrating stones were treated with ESWL.

The overall success rate was $(96 \%)$ in group A and $(88 \%)$ in group B with no significant difference between both groups and it was found that endoscopic interventions without preparation with tamsulosin were associated with increased complication or failure rates.

Our study had some limitations; first, relatively few patients were included in each group. Second, the exact timing of the endoscopic steps, such as bladder access, ureteral access, lithotripsy and ureteral stenting, as well as subjective experiences and stone factors such as stone composition, were not evaluated in the present study.

Thus, the results of this study should be considered as preliminary data, which requires confirmation with a larger sample size in the future.

\section{Conclusions:}

From the early results we can conclude that:

- The use of $\mathrm{a}^{-} 1 \mathrm{~A}$ blocker as a part of expulsive therapy for ureteric stones may facilitate any subsequent ureteroscopic manipulation for treatment of the stones that failed medical treatment.

- The use of $\mathrm{a}^{-}{ }_{1 \mathrm{~A}}$ blocker prior to URS for distal ureteric stones is associated with less need for ureteral orifice dilatation as well as post procedure stenting using double $\mathbf{J}$ stent.

- The URS procedure is considered overall easier among patients who received $\mathrm{a}^{-}{ }_{1 \mathrm{~A}}$ blockers before the procedur and enjoyed higher success rate.

\section{References}

1- PRICOP C., NOVAC C., NEGRU D., et al.: Can selective alpha blockers help the spontaneous passage of the stones located in the uretero bladder junction. Rev. Med. Chir. Soc. Med. Nat., 108: 128-33, 2004. 
2- DELLABELLA M., MILANESE G., et al.: Efficacy of tamsulosin in the medical management of juxtavesical ureteral stones. J. Urol., 170: 2202-5, 2003.

3- BADER M.J., EISNER B., PORPIGLIA F., et al.: Contemporary management of ureteral stones. Eur. Urol., 61 (4): 764-72, 2012.

4- ZHANG M., DING S., LU J., et al.: Comparison of tamsulosin with extracorporeal shock wave lithotripsy in treating distal ureteral stones. Chinese Med. J., 122 (7): 798-801, 2009.

5- NABI G., DOWNEY P., KEELEY F., et al.: Extracorporeal shock wave lithotripsy (ESWL) versus ureteroscopic management for ureteric calculi. Cochrane Database Syst. Rev., (1): CD006029, 2007.

6- ISLAM M. and MALIK A.: Ureteroscopic pneumatic versus extracorporeal shock wave lithotripsy for lower ureteral stones. J. Coll. Physicians. Surg. Pak., 22 (7): 444-7, 2012.

7- LEIJTE J.A., ODDENS J.R. and LOCK T.M.: Holmium laser lithotripsy for ureteral calculi: Predictive factors for complications and success. J. Endourol., 22 (2): 257-60, 2008.

8- S. MANDAL, A. GOEL, M.K. SINGH, et al.: Clavien classification of semirigid ureteroscopy complications: A prospective study Urology, 80 November (5), pp. 9951001, 2012.

9- ROMERO V., AKPINAR H. and ASSIMOS D.G.: Kidney stones: A global picture of prevalence, incidence, and associated risk factors. Rev. Urol., 12 (2-3): e86-96, 2010.

10- WILSON D.M.: Clinical and laboratory approaches for evaluation of nephrolithiasis. J. Urol., 141: 770-4, 1989.

11- RAMAKUMAR S., PATTERSON D.E., LEROY A.J., et al.: Prediction of stone composition from plain radiographs: A prospective study. J. Endo. Urol., 13: 397-401, 1999.

12- M.S. GRIWAN, S.K. SINGH, H. PAUL, et al.: The efficacy of tamsulosin in lower ureteral calculi Urol. Ann., 2 (2): pp. 63-6, 2010.

13- C. TURK, T. KNOLL, PETRIK, et al.: Guidelines on urolithiasis EAU, 2014.

14- M. ZHANG, S. DING, J. LU, et al.: Comparison of tamsulosin with extracorporeal shock wave lithotripsy in treating distal ureteral stones Chin. Med. J., 122 (7): pp. 798-801, 2009.

15- O. TANRIVERDI, M.S. SILAY, M. KADIHASANOGLU, et al.: Revising the predictive factors for intra-operative complications of rigid ureteroscopy: A 15-year experience Urol. J., 9 (Spring (2)), pp. 457-64, 2012.

16- P. GEAVLETE, R. MULTESCU and B. GEAVLETE: Pushing the boundaries of ureteroscopy: Current status and future perspectives Nat. Rev. Urol., 11 (7): pp. 37382, 2014.

17- O.F. MILLER and C.J. KANE: Time to stone passage for observed ureteral calculi: A guide for patient education J. Urol., 162 (3 Pt. 1), pp. 688-90, 1999.

18- M.K. SAMPLASKI, B.H. IRWIN and M. DESAI: Lessinvasive ways to remove stones from the kidneys and ureters Cleve Clin. J. Med., 76 (10): pp. 592-8, 2009.

19- GARVIN T.J. and CLAYMAN R.V.: Balloon dilation of the distal ureter to 24Fr: An effective method of ureteroscopic stone retrieval. J. Urol., 146: 742-5, 1991.

20- RICHTER S., MO SHE S., LOBIK L., et al.: Early postureteroscopy vesicureteral reflux-A temporary and infrequent complication: Prospective study. J. Endourol., 1999; 13: 365-366.

21- STOLLER M.L., WOLF Jr. J.S., HOFMANN R., et al.: Ureteroscopy without routine balloon dilation: An outcome assessment. J. Urol., 147: 1238-42, 1992.

22- KOURAMBAS J., BYRNE R.R. and PREMINGER G.M.: Does a ureteral access sheath facilitate ureteroscopy? J. Urol., 165: 789-93, 2001.

23- CHEN Y.T., CHEN J., WONG W.Y., et al.: Is ureteral stenting necessary after uncomplicated ureteroscopic lithotripsy? A prospective, randomized controlled trial. J. Urol., 167 (5): 1977-80, 2002.

24- NABI G., COOK J., N'DOW J., et al.: Outcomes of stenting after uncomplicated ureteroscopy: Systematic review and meta-analysis. B.M.J., 334 (7593): 572, 2007.

25- HALEBLIAN G., KIJVIKAI K., De La ROSETTE J., et al.: Ureteral stenting and urinary stone management: A systematic review. J. Urol., 179 (2): 424-30, 2008.

26- CARTER S.S.T.C., COX R. and WICKHAM J.E.A.: Complications associated with ureteroscopy. Br. J. Urol., 58: 625-8, 1986.

27- FLAM T.A., MALONE M.J. and ROTH R.A.: Complications of ureteroscopy. Urol. Clin. North. Am., 15: $167-$ 81, 1988.

28- HARMON W.J., SERSHON P.D., BLUTE M.L., et al.: Ureteroscopy: Current practice and long-term complications. J. Urol., 157: 28-32, 1997. 


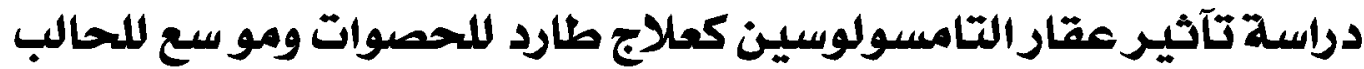

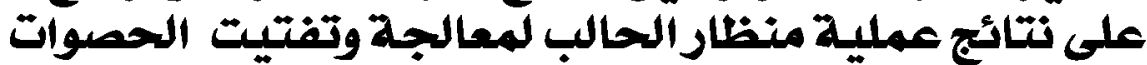 بالجزء الآسفل من الحالب لهالب}

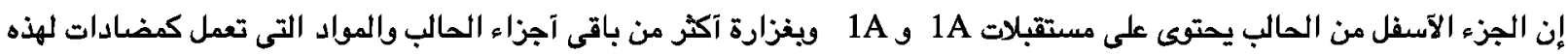

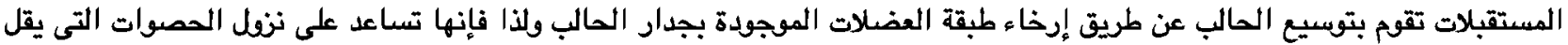

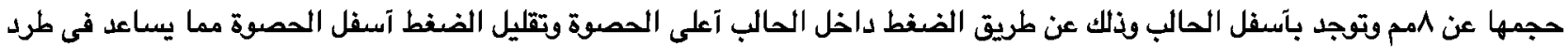
تلك الحصوات

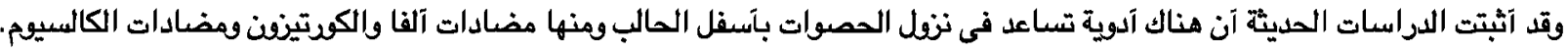
وآيضا قد آثبتت الدراسات آنه يمكن التخلص من حصوات الحالب بالجزء السفلى عن طريق تفتيتها بإستخدام الموجات التصادمية آو عن طريق عمل منظار حالب وتفتيتها علما بوجود المضاعفات التى قد تحدث آثناء التفتتيت.

وآيضا هناك عوامل كثيرة تئثر في نجاح عملية التفتيت والتخلص الآمن من تلك الحصوات ومنها حجم الحصوة ومكان الحصوة بالحالب والالات المستخدمة وخبرة فريق العمل.

ويناء على كل هذه الدراسات تبين آن إستخدام مضادات آلفا قبل عمل منظار الحالب يساعد في سهولة عمل المنظار وتقليل المضاعفات التى قد تصدث وتسهيل نزفل الحصوات.

الهدف من الدراسة: الهدف من الدراسة هو تقييم تآثير عقار التامسولوسين كعلاج طارد الحصوات ومو سع للحالب على نتائج عملية منظار الحالب لمعالجة وتفتيت الحصوات بالجزء الآسفل من الحالب.

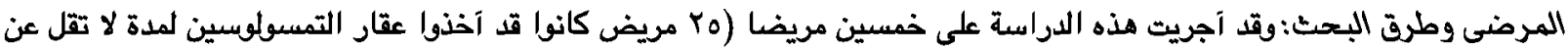

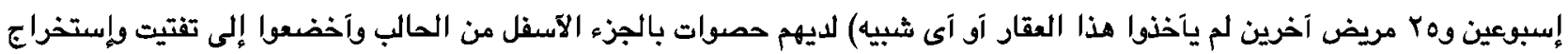

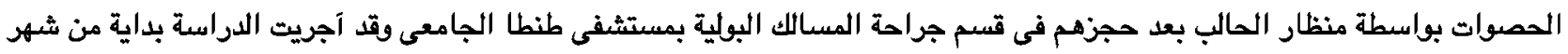

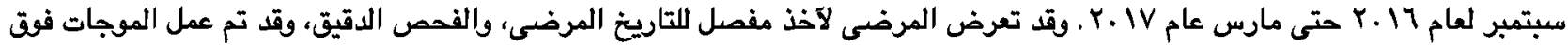

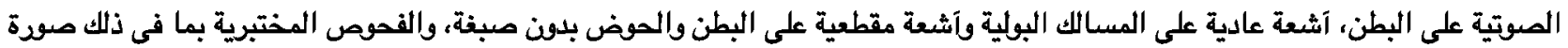

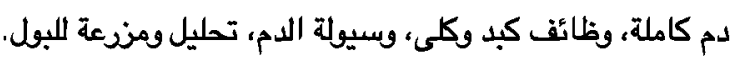

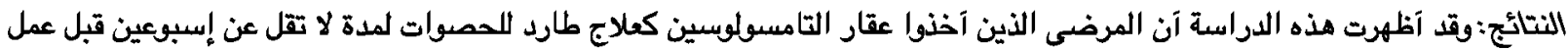

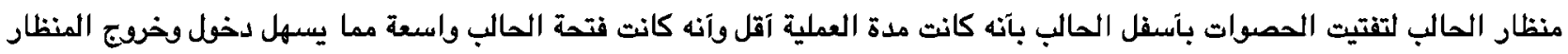

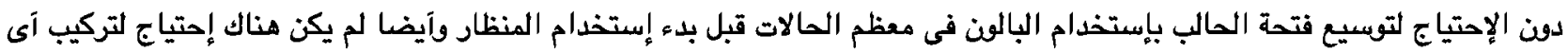

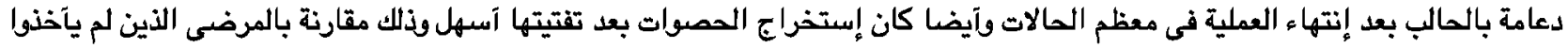
هذا العقار آو آى شبيه قبل عمل المنظار.

وآيضا المرضى الذين آخذوا هذا العقار قبل المنظار كان إحتياجهم المسكنات المخدرة بعد العملية آقل من المرضى الآخرين وآيضا نسبة حدوث إرتفاع بدرجة الحرارة كانت آقل لدى المرضى الذين الذين آخذوا عقار التامسولوسين.

الإستتتاج:

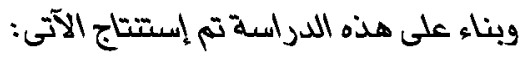
• إن إستخدام العقارات الموسعة للحالب كعقار التامسولوسين والتى التى تساعد ف طرد حصوات الحالب بآنها تقوم بتسهيل عمل منظار الحالب الذى يستخدم فى تفتيت الحصوات بآسفل الحالب.

• إن إستخدام هذه العقارات قبل عمل المنظار يقلل الإحتياج إلى توسيع فتحة الحالب قبل لخفل المنظار وآيضا يقلل الإحتياج لوضع آى لدعامة بالحالب بعد إنتهاء العملية. • إن عملية منظار الحالب اللتفتيت كانت آسهل مع إستخدام العقارات الموسعة للحالب كمقار التامسولوسين وكانت المضاعفات آثل (كالحمى ما بعد العملية وإستخدام المسكنات المخدرة). 